\title{
Apresentação
}

\section{Eni de Mesquita Samara}

Diretora do Museu Paulista
Este número dos Anais do Museu Paulista apresenta artigos de especialistas sobre uma ampla variedade de aspectos relativos à cultura material e à gestão de museus. A criatividade no tratamento metodológico de fontes iconográficas é um dos eixos presente neste conjunto de trabalhos, em que também se destacam inovadoras interpretações sobre a difusão de padrões neoclássicos no Brasil ao longo do século XIX.

Renato Cymbalista abre a seção Cultura Material abordando o papel das relíquias sagradas católicas no processo de cristianização da América Portuguesa durante os séculos XVI e XVII, documentando sua utilização na estruturação do espaço colonial e o caráter mediador destes elementos no contato entre missionários e populações indígenas. As dimensões religiosas também constituem a temática do artigo de Luiz Lima Vailati, que interpreta a produção de fotografias de crianças mortas, os "anjos", em São Paulo durante o século XIX, buscando compreender práticas culturais e espirituais em relação à morte. Fotografias oitocentistas pertencentes à família Ribeiro de Avellar, grandes produtores de café do vale do Paraíba fluminense são as fontes privilegiadas que Mariana Muaze utiliza para compreender formas de representação social ligadas a uma família da elite imperial brasileira.

Documentação iconográfica de diferentes tipologias são abordadas nos artigos seguintes, de Annateresa Fabris, Pedro Rossetto e Roseli D'Elboux. Fabris discute o impacto da produção fotográfica de Aleksandr Rodtchenko na União Soviética, estudo desenvolvido no âmbito do projeto "O desafio do olhar: arte e fotografia no período das vanguardas históricas", que já teve um primeiro artigo publicado no v. 13, n. 1 dos Anais. A reconstituição do traçado da "estrada dos 
Goiases", no trecho em que atravessa a cidade de Campinas, é o tema de Rossetto, que reinterpreta fotografias aéreas para compreender a importância desta via na estruturação urbana da cidade, debatendo com as colocações já presentes na historiografia. A disseminação do uso de renques de palmeira imperial no vale do Paraíba paulista e na cidade de São Paulo são o tema de D'Elboux, que documenta, mediante uso de fotografias e cartões-postais, a difusão desta solução neoclássica do paisagismo brasileiro oitocentista a partir do exemplo fundador constituído pelo Jardim Botânico do Rio de Janeiro.

Na seção Museus, Teresa Toledo de Paula realizou um minucioso estudo das práticas curatoriais relacionadas aos acervos têxteis em museus da Universidade de São
Paulo, discutindo os critérios que nortearam a gestão desta tipologia de acervo nestas instituições.

Elaine Dias, na seção Documentos, discute as negociações que permitiram a vinda da Missão Francesa de 1816 e reinterpreta as condições em que se deu a introdução da escola neoclássica no Brasil.

Este número dos Anais do Museu Paulista é finalizado com uma resenha de Heliana Angotti Salgueiro sobre uma obra recente sobre a trajetória e a contribuição conceitual de Georges Henri-Rivière, figura chave da Museologia francesa durante o século XX.

Assim, diante desse leque de opções que este volume oferece, mais uma vez o Museu Paulista atende ao público especializado interessado nos estudos de cultura material. 